\title{
Breast Cancer in Association with Thyroid Disorders
}

\author{
Dr. Anil Batta
}

Professor \& Head, Department Of Medical Biochemistry, Govt. Medical College, Medical Enclave, Amritsar, Punjab 143001, India

DOI: $10.36348 /$ sijb.2019.v02i11.001 $\quad$ | Received: 13.11.2019| Accepted: 20.11.2019 | Published: 28.11 .2019

*Corresponding author: Dr. Anil Batta

\section{Abstract}

The relationship between breast cancer and thyroid diseases is controversial. Discrepant results have been reported in the literature. The incidences of autoimmune and nonautoimmune thyroid diseases were investigated in patients with breast cancer and age-matched control individuals without breast or thyroid disease. Methods: Clinical and ultrasound evaluation of thyroid gland, determination of serum thyroid hormone and antibody levels, and fine-needle aspiration of thyroid gland were performed in 150 breast cancer patients and 100 control individuals. Results: The mean values for anti-thyroid peroxidase antibodies were significantly higher in breast cancer patients than in control individuals $(P=$ 0.030 ). The incidences of autoimmune and nonautoimmune thyroid diseases were higher in breast cancer patients than in control individuals (38\% versus $17 \%, P=0.001 ; 26 \%$ versus $9 \%, P=0.001$, respectively). Conclusion: Our results indicate an increased prevalence of autoimmune and nonautoimmune thyroid diseases in breast cancer patients. There is always a controversy on the relationship between breast cancer and thyroid disorders. As these tissues, i.e., breast and thyroid, originate embryologically from the same type of cells, hypothyroid/hyperthyroid females are more prone to develop benign or malignant breast tumors. The studies on breast cancer patients indicate increased thyroid disorders in breast cancer patients, most commonly Hashimoto's thyroiditis accounts to increased thyroid disorders in these patients. This is independent of hormonal receptor status of the patient. These findings suggest the usefulness of screening for thyroid disease in any patient with breast cancer.

Keywords: Anti-thyroid peroxidase, breast cancer, thyroid.

Copyright @ 2019: This is an open-access article distributed under the terms of the Creative Commons Attribution license which permits unrestricted use, distribution, and reproduction in any medium for non-commercial use (NonCommercial, or CC-BY-NC) provided the original author and source are credited.

\section{INTRODUCTION}

Thyroid peroxidase (TPO) is a key enzyme in the synthesis of thyroid hormone. TPO is involved in thyroid hormone synthesis (organification and coupling reactions). After iodide enters the thyroid, it is trapped and transported to the apical region of thyroid follicular cells. The oxidation of iodide to iodine is catalyzed by the enzyme TPO. This reaction requires $\mathrm{H}_{2} \mathrm{O}_{2}$ and NADPH and NADPH is from Hexose MonoPhosphate (HMP) shunt pathway. The coupling of iodine atom to protein thyroglobulin is also catalyzed by TPO [1].

$$
\begin{aligned}
& \text { Iodid e }(\mathrm{I}-\mathrm{r} \longrightarrow \text { Active Iodine }(\mathrm{I}+) \\
& \mathrm{H}_{2} \mathrm{O}_{2} \quad \mathrm{H}_{2} \mathrm{O}
\end{aligned}
$$

TPO is a major antigen corresponding to thyroid-microsomal autoantibodies. AntiTPO autoantibodies are very important to diagnose autoimmune thyroid diseases and also in estimating its clinical course [2]. Human TPO was found to bind to both IgG and IgM from patients with autoimmune thyroid diseases. The binding of IgG to microsomes is inhibited by TPO. ${ }^{[3]}$ Hashimoto's thyroiditis and Grave's disease are commonly seen autoimmune thyroid diseases. There are two specific regions of antiTPO antibodies binding, and there are differences in the autoantibody response to TPO in Hashimoto's and Grave's diseases [4]. Systemic lupus erythrematosus (SLE) is an autoimmune disease which also secretes antibodies to TPO, these antibodies are of $\operatorname{IgG}$ type. These IgG antibodies do not inhibit TPO activity in contrast to $\operatorname{IgG}$ secreted from patients of thyroid disorders [5].

Autoimmune thyroid disease is detected mostly by measuring circulating antibodies to thyroglobulin which is uncommon measurement of antibodies to TPO that gives reliable information about autoimmune thyroid disease. Eighty percent of Grave's disease patients have high levels of anti-TPO antibodies. About $4 \%$ of subclinical hypothyroid patients with positive TPO antibodies develop clinical hypothyroidism. TPO antibodies fix complement, and a complex of membrane and complement are formed, these complexes are present in autoimmune thyroid 
disease patients. Placental passage of these antibodies has no effect on fetal thyroid, which indicates that $\mathrm{T}$ cell damage is required to initiate autoimmune damage to thyroid [1].

\section{Effect on Breast}

There is always a controversy on the relationship between breast cancer and thyroid disorders. As these tissues, i.e., breast and thyroid, originate embryologically from the same type of cells, hypothyroid/hyperthyroid females are more prone to develop benign or malignant breast tumors. There is an increased prevalence of hyperthyroidism in postmenopausal women. A study conducted on postmenopausal breast cancer patients showed an increased thyroid hormone/estradiol ratio, which suggests a tumor growth promoting effect caused by this misbalance. Sodium/iodide symporter (NIS) gene is expressed approximately one-third of human breast cancer tissue. Its expression is independent of the hormonal receptor status of the patient (TSH-R gene, ER/PR). The studies on breast cancer patients indicate increased thyroid disorders in breast cancer patients, most commonly Hashimoto's thyroiditis accounts to increased thyroid disorders in these patients. This is independent of hormonal receptor status of the patient. These findings suggest the usefulness of screening for thyroid disease in any patient with breast cancer. In a study conducted on females with breast-related problems, we found that $3.2 \%(n=31)$ are having thyroid disorders (goiter, hypothyroidism) and a raise in anti-TPO levels is found in females with the advancement in their age.

\section{Patient Selection}

A total of 150 consecutive women with breast cancer and 100 age-matched control women were included in the present study, during the period from May 2017 to December 2018. Breast cancer patients were 38-80 years old (median age 63 years) and were without any known thyroid disease. Three or four weeks after surgical procedure, the patients were evaluated before starting chemotherapy, hormone therapy or radiotherapy.

\section{EXAMINATION}

All patients underwent the following five examinations. First, each patient underwent palpation of the thyroid gland. Second, ultrasonographic evaluation of the thyroid gland was conducted by the same radiologist using an ultrasound scan fitted with a handheld 6.6-11 MHz linear transducer. The volume of each lobe was calculated using the following formula: volume $=$ length $\times$ width $\times$ height $\times 0.479$ [19]. Upper and lower normal lobe volume limits were $18 \mathrm{ml}$ and 10 $\mathrm{ml}$, respectively. Third, serum free triiodothyronine $\left(\mathrm{T}_{3}\right)$ and free thyroxin $\left(\mathrm{T}_{4}\right)$ levels were determined, based on a solid-phase ${ }^{15}$ radioimmunoassay designed for the quantitative measurement of free $T_{3}$ and free $T_{4}$ levels in serum using Coat-A-Count kit containing radioactive
$\mathrm{I}^{125}-\mathrm{T}_{3}$ or $-\mathrm{T}_{4}$ analogue (DPC, Los Angeles, CA, USA). Also, serum thyroid-stimulating hormone (TSH) levels were measured using a immunoradiometric assay designed for quantitative measurement of TSH in serum using Coat-A-Count kit containing radioactive $\mathrm{I}^{125}$ polyclonal anti-TSH (Diagnostics Products Corporations, Los Angeles, CA, USA). The normal ranges were $2.2-6.8 \mathrm{pmol} / 1(1.4-4.4 \mathrm{pg} / \mathrm{ml})$ for free $\mathrm{T}_{3}$, $0.8-2.0 \mathrm{ng} / \mathrm{dl}$ for free $\mathrm{T}_{4}$ and $0.3-5.0 \mu \mathrm{IU} / \mathrm{ml}$ for $\mathrm{TSH}$. Fourth, all patients underwent serological determination of thyroid autoantibodies based on a direct Anti-TPO radioimmunoassay kit for quantitative determination of anti-TPO autoantibodies (Immunotech, Prague, Czech Republic). Also, autoantibodies specific for thyroglobulin were measured using a quantitative indirect enzyme immunoassay based on the sandwich method (antithyroglobulin immunoradiometric assay kit; Immunotech, Prague, Czech Republic). The normal ranges were $0-60 \mathrm{IU} / \mathrm{ml}$ for antithyroglobulin antibodies and $0-20 \mathrm{IU} / \mathrm{ml}$ for anti-TPO antibodies. Finally, after informed consent had been obtained from each patient, fine-needle aspiration (FNA) of the thyroid gland was performed in breast cancer patients who had a palpable thyroid nodule. The aspiration was performed using a 22 guage needle and the smears were air dried and dyed with May-Gruenwald-Giemsa dye. FNA smears were considered diagnostic for autoimmune thyroiditis if there was an abundance of lymphocytes and plasmacytes in a diffuse pattern and/or coexistence of many lymphocytes and oxyphilic epithelial cells. Patients were separated into three groups according to clinical and ultrasound findings: normal gland, diffuse goitre and nodular goitre. Those women without any breast or thyroid disease were the control group. Patients were also classified into the following subgroups according to menopausal and oestrogen receptor (ER) status: premenopausal and postmenopausal; and ER negative and ER positive.

\section{DISCUSSION}

The possible interactions between thyroid gland and breast tissue are based on the common property of the mammary and thyroid epithelial cell to concentrate iodine by a membrane active transport mechanism [18] as well as on the presence of TSH receptors in fatty tissue, which is abundant in mammary gland [21]. Additionally, some endocrine stimuli identified in thyroid products that exert a simultaneous action on the breast and the various thyroid antibodies, which could also interact with receptors on breast tumors, have been postulated to be responsible for the coincidence of mammary and thyroid gland disorders $[15,22]$. The present study found a high prevalence of goitre as well as a high prevalence of autoimmune thyroiditis, confirmed mainly by antibody positivity, in breast cancer patients. An association of autoimmune thyroid disease with breast cancer has been reported in the literature $[1,16]$. In those studies, increased serum levels of thyroid antibodies were identified. Although Mittra and coworkers [1] found the levels of thyroid 
antibodies in British women to be lower than those in Japanese women, they found no differences between incidences in breast cancer among women of either race. With the use of specific immunoassays for TPO and thyroglobulin antibodies, an increased level of TPO has been demonstrated in breast cancer. It has been proposed that the presence of thyroid abnormalities may influence breast cancer progression [19]. A recent report suggested a better prognosis for breast cancer among patients with increased levels of TPO [19]. It has been proposed that the immune response might be directed both by tumour and by thyroid tissue [20], or that the tumour and thyroid tissue share common properties, as they both express TPO and the sodium iodide symporter gene. Although high TPO level has been shown to be a very important factor in antibodydependent cell cytotoxicity in the thyroid, and there may be a possible association between autoimmune thyroiditis and the immune system, there is no agreement on the significance of its association with breast cancer. The relationship between thyroiditis and prognostic factors for breast cancer such as ER and stage has been investigated. In one study [1], a higher frequency of thyroiditis was described in more advanced stages of breast cancer. In another study reported by Giani and coworkers [18] no relationship was found between ER status and the presence of serum thyroid antibodies. We found no correlations among ER status, menopausal status and thyroid antibody levels. In addition to the reported high prevalence of autoimmune thyroiditis among breast cancer patients, the incidence of breast cancer among patients with chronic thyroiditis has been investigated. In a study conducted by Ito and Maruchi [2], those investigators reported that there was an increase in risk for breast cancer among patients with Hashimoto's thyroiditis. The present study found a high prevalance of goitre as well as a high prevalence of autoimmune thyroiditis, confirmed mainly by antibody positivity, in breast cancer patients. An association of autoimmune thyroid disease with breast cancer has been reported in the literature $[1,16]$. In those studies, increased serum levels of thyroid antibodies were identified. Although
Mittra and coworkers [1] found the levels of thyroid antibodies in British women to be lower than those in Japanese women, they found no differences between incidences in breast cancer among women of either race. With the use of specific immunoassays for TPO and thyroglobulin antibodies, an increased level of TPO has been demonstrated in breast cancer.

It has been proposed that the presence of thyroid abnormalities may influence breast cancer progression. A recent report suggested a better prognosis for breast cancer among patients with increased levels of TPO [19]. It has been proposed that the immune response might be directed both by tumour and by thyroid tissue [20], or that the tumour and thyroid tissue share common properties, as they both express TPO and the sodium iodide symporter gene. Although high TPO level has been shown to be a very important factor in antibody-dependent cell cytotoxicity in the thyroid, and there may be a possible association between autoimmune thyroiditis and the immune system, there is no agreement on the significance of its association with breast cancer.

The relationship between thyroiditis and prognostic factors for breast cancer such as ER and stage has been investigated. In one study [1], a higher frequency of thyroiditis was described in more advanced stages of breast cancer. In another study reported by Giani and coworkers [18] no relationship was found between ER status and the presence of serum thyroid antibodies. We found no correlations among ER status, menopausal status and thyroid antibody levels. In addition to the reported high prevalence of autoimmune thyroiditis among breast cancer patients, the incidence of breast cancer among patients with chronic thyroiditis has been investigated. In a study conducted by Ito and Maruchi [2], those investigators reported that there was an increase in risk for breast cancer among patients with Hashimoto's thyroiditis.

Breast Cancer in Association with Thyroid Disorders

Table-1: Patient distribution according to clinical and ultrasound evaluation of thyroid

\begin{tabular}{|l|l|l|l|}
\hline & Patients (n) & Control (n) & $\boldsymbol{p}$ \\
\hline Normal Gland & $63(42)$ & $70(70)$ & 0.001 \\
\hline Diffuse goitre & $12(8)$ & $4(4)$ & 0.29 \\
\hline Nodular Goitre & $75(50)$ & $26(26)$ & 0.001 \\
\hline
\end{tabular}

The separation of patients into groups on the basis of histopathological diagnosis is shown in Table1. A total of $118(79 \%)$ patients had invasive ductal carcinoma, $15(10 \%)$ had invasive lobular carcinoma and $17(11 \%)$ had mixed (invasive ductal and lobular) carcinoma. In breast cancer patients, diffuse goitre was identified in 12 cases $(8 \%)$ and nodular goitre in 75 cases $(50 \%)$. In the remaining $(42 \%)$ patients, thyroid glands were totally normal by ultrasound and physical examination. In the control group, diffuse goitre was identified in four (4\%) and nodular goitre in $26(26 \%)$. Thus, the prevalence of nodular goitre in the cancer group was higher, and this finding was statistically significant (50\% versus $26 \% ; P=0.001$; Table- 1 ). With respect to thyroid volumes, measured ultrasonographically, the mean volumes of diffuse thyroid gIand were $23.1 \mathrm{ml}$ (range 17-26 ml) in the breast cancer patients and $21.9 \mathrm{ml}$ (range 16-27 ml) in the control group. The mean volumes of nodular goitre in breast cancer patients and in the control group were 
$19.2 \mathrm{ml}$ (range 13-21 ml) and $18.7 \mathrm{ml}$ (range 11-21 $\mathrm{ml})$, respectively.
From: Breast cancer in association with thyroid disorders

Table-2: Serum Thyroid Hormone and Antibody Levels

\begin{tabular}{|l|l|l|}
\hline & Patients & Control \\
\hline Free $\mathrm{T}_{3}(\mathrm{pmol} / \mathrm{l})$ & $8.47 \pm 0.75$ & $4.48 \pm 0.75$ \\
\hline Free $\mathrm{T}_{4}(\mathrm{ng} / \mathrm{dl})$ & $2.64 \pm 0.91$ & $1.42 \pm 0.31$ \\
\hline $\mathrm{TSH}(\mu \mathrm{IU} / \mathrm{ml})$ & $3.12 \pm 1.40$ & $1.46 \pm 0.82$ \\
\hline TPO antibodies $(\mathrm{IU} / \mathrm{ml})$ & $105.82 \pm 21.46$ & $23.08 \pm 4.16$ \\
\hline Thyroglobulin antibodies $(\mathrm{IU} / \mathrm{ml})$ & $140.92 \pm 21.52$ & $27.75 \pm 7.60$ \\
\hline
\end{tabular}

$\mathrm{T}_{3}$, Triiodothyronine, $\mathrm{T}_{4}$, Thyroxin, TPO, Thyroid Peroxidase; TSH, Thyroid-Stimulating Hormone

Evaluation of thyroid function was based on serum thyroid hormones. The mean values for serum thyroid hormones were $8.47 \pm 0.75 \mathrm{pmol} / 1$ for free $\mathrm{T}_{3}$, $2.64 \pm 0.91 \mathrm{ng} / \mathrm{dl}$ for free $\mathrm{T}_{4}$ and $3.12 \pm 1.40 \mu \mathrm{IU} / \mathrm{ml}$ for $\mathrm{TSH}$ in breast cancer patients, and $4.48 \pm 0.75 \mathrm{pmol} / \mathrm{l}$, $1.42 \pm 0.31 \mathrm{ng} / \mathrm{dl}$ and $1.46 \pm 0.82 \mu \mathrm{IU} / \mathrm{ml}$, respectively, in the control group. The differences between breast cancer patients and the control group in mean serum free $T_{3}$, free $T_{4}$ and TSH levels were not statistically significant (Table-2). Nontoxic goitre was found in 77 $(51 \%)$ of the breast cancer patients and in $29(29 \%)$ of the control individuals $(P=0.001$; Table-3).

From: Breast cancer in association with thyroid disorders

Table-3: Classification of Patients In Relation To Functional Thyroid Diseases

\begin{tabular}{|l|l|l|}
\hline & Patients $(\boldsymbol{n}$ [\%]) & Control $(\boldsymbol{n}$ [\%]) \\
\hline Hyperthyroidism & $6(4)$ & $1(1)$ \\
\hline Hypothyroidism & $4(3)$ & - \\
\hline Nontoxic goitre & $77(51)$ & $29(29)$ \\
\hline
\end{tabular}

The mean values for serum thyroid autoantibodies were $105.82 \pm 21.46 \mathrm{IU} / \mathrm{ml}$ for anti-TPO antibodies and $140.92 \pm 21.52 \mathrm{IU} / \mathrm{ml}$ for antithyroglobulin antibodies in breast cancer patients, and $23.08 \pm 4.16 \mathrm{IU} / \mathrm{ml}$ and $27.75 \pm 7.60 \mathrm{IU} / \mathrm{ml}$, respectively, in the control group. Thus, the mean value for serum anti-TPO antibodies was higher in breast cancer patients than in the control group $(P=0.030)$, whereas the difference between the groups in mean values for serum antithyroglobulin antibodies was not statistically significant $(P=0.094)$. Autoimmune thyroiditis was defined by increased serum levels of at least one thyroid autoantibody or diagnostic FNA findings, or both. Among the breast cancer patients, autoimmune thyroiditis was diagnosed by autoantibodies in $42(28 \%)$, by FNA in four $(2 \%)$ and by both in $11(7 \%)$. The difference in the frequency of autoimmune thyroiditis between breast cancer patients and control group was statistically significant $(P=$ 0.001; Table-4). On the other hand, non-AITD was identified, with neither thyroid autoantibody in plasma nor FNA findings specific to autoimmune thyroiditis, in the patients with nodular or diffuse goitre.

From: Breast Cancer In Association With Thyroid Disorders

Table-4: Classification of Patients Based On Autoimmune and Non-Autoimmune Thyroid Disorders

\begin{tabular}{|l|l|l|l|}
\hline & Patients $(\boldsymbol{n}[\%])$ & Controls $(\boldsymbol{n}[\%])$ & $P$ \\
\hline Normal & $54(36)$ & $74(74)$ & 0.0001 \\
\hline Non-AITD & $39(26)$ & $9(9)$ & 0.001 \\
\hline Autoimmune thyroiditis & $57(38)$ & $17(17)$ & 0.001 \\
\hline
\end{tabular}

1. AITD, autoimmune thyroid disease.

\section{CONCLUSION}

Thus, in conclusion serum antiTPO levels are raised in thyroid disorders especially autoimmune thyroid diseases and all the patients with breast cancer should be screened for thyroid disorders before therapy. This helps us to know the relationship between breast cancer and thyroid disorders. Primary hypothyroidism is one of the most common endocrine disorders encountered and managed by primary care providers. Unfortunately, the symptoms of hypothyroidism are extremely non-specific and otherwise highly prevalent in the population. Therefore, providers need to rely on biochemical testing to confirm or rule-out the diagnosis of hypothyroidism. This long-standing reliance on the TSH has come under increased scrutiny in the public domain, and many alternative and traditional medicine providers are now questioning the reliability of standard biochemical testing of thyroid function. Many patients struggle with a multitude of these non-specific complaints, and in their quest for answers become upset 
when they are told their thyroid function is normal. As reviewed, true hypothyroidism in the setting of a normal TSH is highly unlikely, with an estimated prevalence of perhaps 1 case per 1500 patients. It is uncertain, therefore, whether the assessment of a single free T4 is cost-effective in the assessment of a patient's thyroid status. If a free $\mathrm{T} 4$ test is obtained, the limitations of the assay method employed need to be considered. Lastly, the assessment of anti-TPO ABs should be avoided in non-pregnant patients with a normal TSH, as treatment decisions based on the presence or absence of these antibodies is not supported by current clinical guidelines. The increasingly maligned TSH is still the best, and often only, thyroid function test that is needed in the assessment of most patients.

\section{REFERENCES}

1. Ditsch, N., Liebhardt, S., Von Koch, F., Lenhard, M., Vogeser, M., Spitzweg, C., ... \& Toth, B. (2010). Thyroid function in breast cancer patients. Anticancer research, 30(5), 1713-1717.

2. Lemaire, M., \& Baugnet-Mahieu, L. (1986). Nuclear thyroid hormone receptors in human cancer tissues. Anticancer research, 6(4), 695-700.

3. Nogueira, C. R., \& Brentani, M. M. (1996). Triiodothyronine mimics the effects of estrogen in breast cancer cell lines. The Journal of steroid biochemistry and molecular biology, 59(3-4), 271279.

4. Humes, H. D., Cieslinski, D. A., Johnson, L. B., \& Sanchez, I. O. (1992). Triiodothyronine enhances renal tubule cell replication by stimulating EGF receptor gene expression. American Journal of Physiology-Renal Physiology, 262(4), F540-F545.

5. Hall, L. C., Salazar, E. P., Kane, S. R., \& Liu, N. (2008). Effects of thyroid hormones on human breast cancer cell proliferation. The Journal of steroid biochemistry and molecular biology, 109(1-2), 57-66.

6. Tang, H. Y., Lin, H. Y., Zhang, S., Davis, F. B., \& Davis, P. J. (2004). Thyroid hormone causes mitogen-activated protein kinase-dependent phosphorylation of the nuclear estrogen receptor. Endocrinology, 145(7), 3265-3272.

7. Oh, H. J., Chung, J. K., Kang, J. H., Kang, W. J., Noh, D. Y., Park, I. A., ... \& Lee, M. C. (2005). The relationship between expression of the sodium/iodide symporter gene and the status of hormonal receptors in human breast cancer tissue. Cancer research and treatment: official journal of Korean Cancer Association, 37(4), 247250.

8. Turken, O., NarIn, Y., DemIrbas, S., Onde, M. E., Sayan, O., KandemIr, E. G., ... \& Ozturk, A. (2003). Breast cancer in association with thyroid disorders. Breast Cancer Research, 5(5), R110113.

9. Giani, C., Fierabracci, P., Bonacci, R., Gigliotti, A., Campani, D., De Negri, F, ... \& Pinchera, A.
(1996). Relationship between breast cancer and thyroid disease: relevance of autoimmune thyroid disorders in breast malignancy. The Journal of Clinical Endocrinology \& Metabolism, 81(3), 990994.

10. Dohán, O., \& Carrasco, N. (2003). Advances in $\mathrm{Na}+/ \mathrm{I}-$ symporter (NIS) research in the thyroid and beyond. Molecular and cellular endocrinology, 213(1), 59-70.

11. Tazebay, U. H., Wapnir, I. L., Levy, O., Dohan, O., Zuckier, L. S., Zhao, Q. H., ... \& Carrasco, N. (2000). The mammary gland iodide transporter is expressed during lactation and in breast cancer. Nature medicine, 6(8), 871.

12. Wapnir, I. L., Van De Rijn, M., Nowels, K., Amenta, P. S., Walton, K., Montgomery, K., ... \& Carrasco, N. (2003). Immunohistochemical profile of the sodium/iodide symporter in thyroid, breast, and other carcinomas using high density tissue microarrays and conventional sections. The Journal of Clinical Endocrinology \& Metabolism, 88(4), 1880-1888.

13. Rudnicka, L., Sińczak, A., Szybiński, P., Huszno, B., \& Stachura, J. (2003). Expression of the Na $(+) / I \quad(-)$ symporter in invasive ductal breast cancer. Folia histochemica et cytobiologica, 41(1), 37-40.

14. Hammond, M., Hayes, D., \& Dowsett, M. (2010). Pathologists guideline recommendations for immunohistochemical testing of estrogen and progesterone receptors in breast cancer. Breast Care, 134, 907-922.

15. Ferlay, J., Steliarova-Foucher, E., Lortet-Tieulent, J., Rosso, S., Coebergh, J. W. W., Comber, H., ... \& Bray, F. (2013). Cancer incidence and mortality patterns in Europe: estimates for 40 countries in 2012. European journal of cancer, 49(6), 13741403.

16. Michalaki, V., Kondi-Pafiti, A., Gennatas, S., Antoniou, A., Primetis, H., \& Gennatas, C. (2009). Breast cancer in association with thyroid disorders. Journal of BU ON.: official journal of the Balkan Union of Oncology, 14(3), 425-428.

17. Goldman, M. B., Monson, R. R., \& Maloof, F. (1990). Cancer mortality in women with thyroid disease. Cancer Research, 50(8), 2283-2289.

18. Kalache, A., Vessey, M. P., \& McPherson, K. (1982). Thyroid disease and breast cancer: Findings in a large case-control study. British Journal of Surgery, 69(7), 434-435.

19. Simon, M. S., Tang, M. T. C., Bernstein, L., Norman, S. A., Weiss, L., Burkman, R. T., ... \& Marchbanks, P. A. (2002). Do thyroid disorders increase the risk of breast cancer?. Cancer Epidemiology and Prevention Biomarkers, 11(12), 1574-1578.

20. Hoffman, D. A., McConahey, W. M., Brinton, L. A., \& Fraumeni, J. F. (1984). Breast cancer in hypothyroid women using thyroid supplements. JAMA, 251(5), 616-619. 
21. Kuijpens, J. L., Nyklíčtek, I., Louwman, M. W., Weetman, T. A., Pop, V. J., \& Coebergh, J. W. W. (2005). Hypothyroidism might be related to breast cancer in post-menopausal women. Thyroid, 15(11), 1253-1259.

22. Muller, I., Pinchera, A., Fiore, E., Belardi, V., Rosellini, V., Giustarini, E., \& Giani, C. (2011). High prevalence of breast cancer in patients with benign thyroid diseases. Journal of endocrinological investigation, 34(5), 349-352.

23. Cristofanilli, M., Yamamura, Y., Kau, S. W. Bevers, T., Strom, S., Patangan, M., ... \& Hortobagyi, G. N. (2005). Thyroid hormone and breast carcinoma: primary hypothyroidism is associated with a reduced incidence of primary breast carcinoma. Cancer: Interdisciplinary International Journal of the American Cancer Society, 103(6), 1122-1128.

24. Jiskra, J., Barkmanova, J., Limanova, Z., Lanska, V., Smutek, D., Potlukova, E., \& Antosova, M. (2007). Thyroid autoimmunity occurs more frequently in women with breast cancer compared to women with colorectal cancer and controls but it has no impact on relapse-free and overall survival. Oncology reports, 18(6), 1603-1611.

25. Giustarini, E., Pinchera, A., Fierabracci, P., Roncella, M., Fustaino, L., Mammoli, C., \& Giani,
C. (2006). Thyroid autoimmunity in patients with malignant and benign breast diseases before surgery. European journal of endocrinology, 154(5), 645-649.

26. Hardefeldt, P. J., Eslick, G. D., \& Edirimanne, S. (2012). Benign thyroid disease is associated with breast cancer: a meta-analysis. Breast cancer research and treatment, 133(3), 1169-1177.

27. Smyth, P. P. A., Shering, S. G., Kilbane, M. T., Murray, M. J., McDermott, E. W. M., Smith, D. F., \& O'Higgins, N. J. (1998). Serum thyroid peroxidase autoantibodies, thyroid volume, and outcome in breast carcinoma. The Journal of Clinical Endocrinology \& Metabolism, 83(8), 2711-2716.

28. Tosovic, A., Becker, C., Bondeson, A. G., Bondeson, L., Ericsson, U. B., Malm, J., \& Manjer, J. (2012). Prospectively measured thyroid hormones and thyroid peroxidase antibodies in relation to breast cancer risk. International journal of cancer, 131(9), 2126-2133.

29. Takatani, O., Okumoto, T., Kosano, H., Nishida, M., Hiraide, H., \& Tamakuma, S. (1989). Relationship between the levels of serum thyroid hormones or estrogen status and the risk of breast cancer genesis in Japanese women. Cancer Research, 49(11), 3109-3112. 